\title{
Evaluation of Selected Groundnut (Arachis hypogaea L.) Lines for Yield and Haulm Nutritive Quality Traits
}

\author{
Richard Oteng-Frimpong, ${ }^{1}$ Solomon Pigangsoa Konlan, ${ }^{2}$ and Nicholas Ninju Denwar ${ }^{1}$ \\ ${ }^{1}$ CSIR-Savanna Agricultural Research Institute, P.O. Box TL 52, Tamale, Ghana \\ ${ }^{2}$ CSIR-Animal Research Institute, P.O. Box TL 52, Nyankpala Station, Tamale, Ghana \\ Correspondence should be addressed to Richard Oteng-Frimpong; kotengfrimpong@gmail.com
}

Received 25 April 2017; Accepted 5 June 2017; Published 19 July 2017

Academic Editor: Mathias N. Andersen

Copyright (c) 2017 Richard Oteng-Frimpong et al. This is an open access article distributed under the Creative Commons Attribution License, which permits unrestricted use, distribution, and reproduction in any medium, provided the original work is properly cited.

\begin{abstract}
Groundnut, the most important grain legume in Ghana, is largely cultivated under rainfed conditions within the Guinea savanna zone of the country. The pods and haulms are important sources of income for smallholder farmers in the region. There is an emerging market for groundnut haulms as livestock feed in Ghana. A population of 30 groundnut genotypes were evaluated for yield (pod and haulm) and its components as well as good haulm nutritive value. High significant differences were observed among the genotypes for all agronomic traits. Average pod yield ranged from 1.6 to $5.7 \mathrm{t} / \mathrm{ha}$ with SAMNUT 23 and ICGV-IS 13081 being the most productive. Eight out of the 30 genotypes produced haulm yields above $8 \mathrm{t} / \mathrm{ha}$. There was no significant difference among genotypes for in vitro gas production, digestible organic matter, ash, neutral detergent fibre, and metabolizable energy. However, crude protein, crude fibre, and acid detergent fibre were significantly different. Crude protein content was highest (12.53\%) in GAF 1723 and lowest (8.00\%) in ICGV-IS 08837. Genotypes GAF 1723, ICGV 00064, and ICGV-IS 13998 combined good pod/haulm yield with high haulm nutritive quality. Their utilization will improve farmers' income and livelihoods in the Guinea savanna of Ghana.
\end{abstract}

\section{Introduction}

Groundnut is the most important grain legume in Ghana in terms of area under cultivation [1]. The Guinea savanna ecology of Ghana accounts for over $70 \%$ of total groundnut produced in the country [1], making it the most important groundnut region in the country. Within this region, groundnut plays an important role in the livelihoods of small holder farmers as it is estimated that about $90 \%$ of farming households are involved in groundnut production together with other crops [2]. The crop provides highly nutritious meals and a protein substitute for households with fewer resources to acquire meat products $[3,4]$. From agroecological perspective, groundnut improves soil fertility through fixation of atmospheric dinitrogen into the soil $[5,6]$, hence reducing the quantity of synthetic $\mathrm{N}$ fertilizers required. Sale of the grain fetches additional income for the households and the haulms serve as high quality protein fodder for livestock [4].

Groundnut haulms are more palatable and rich in protein compared to stovers of cereals which have low $\mathrm{N}$, high fibre content, and poor digestibility and therefore have low nutritive value and are used as supplementary feed [7]. In male sheep, Prasad et al. [8] reported an average daily voluntary feed intake of more than $4 \%$ of live body weight. This level of voluntary feed intake is on the high side and is rarely seen in animals on any kind of feed except lactating animals [9]. Groundnut haulms are also important in the poultry industry as substituting $6 \%$ of concentrate mixture with groundnut haulms resulted in a $15 \%$ increase in live body weight of broilers compared to the controls [10]. The substantial increase observed was attributed to improved feed intake and high nutrient availability in groundnut haulms. Crude protein concentration of haulms of many groundnut cultivars ranges from 8 to $15 \%$ and ether extract from 1 to $3 \%[11,12]$. Groundnut haulms contain neutral detergent fibre (NDF) of about $47 \%$, acid detergent fibre (ADF), and lignin content around $36.5 \%$ and $6.3 \%$, respectively [13]. Digestibility of groundnut haulms ranges from 74 to $88 \%$ in ruminants and support animals' growth performance even when fed as sole 
feed [14]. Nigam and Blummel [11] also reported an in vitro digestibility between 52 and $61 \%$.

Despite the importance of groundnut, yield on farmers' fields in the Guinea savanna of Ghana remain low (0.5-1.0 t/ha) compared to over $3.0 \mathrm{t} / \mathrm{ha}$ obtained in countries such as China and Brazil $[1,15]$. The low yield is attributed to a myriad of biotic and abiotic factors. The major biotic stress includes early and late leaf spot diseases caused by Cercospora arachidicola S. Hori and Cercosporidium personatum (Berk. \& Curt.), respectively, as well as groundnut rosette disease [16, 17]. These diseases drastically reduce pod yield in groundnut as well as haulm quantity and quality. Aflatoxins produced by Aspergillus flavus and A. parasiticus also reduce grain quality resulting in lower incomes for farmers $[18,19]$. The abiotic constraints include poor soil fertility (lower levels of N, P, and $\mathrm{Ca}$ ) and erratic rainfall which results in intermittent drought [20-23].

In Ghana, groundnut haulm is commonly used as supplementary feed in ruminant production [24] by smallholder farmers who depend largely on natural pasture. This natural pasture is mostly poor in quality during the dry season and supplementation contributes substantially to the performance of animals [25]. Moreover, there is an emerging livestock feed market in Ghana solely based on farm residues with groundnut haulms as one of the most expensive residues [26]. Farmers' with groundnut genotypes that have high haulm yields are therefore better positioned to benefit from this market to boost their income and improve their livelihoods.

It is therefore important to develop groundnut varieties that combine high pod yield with high quality biomass yield for dual purpose utilization. Nigam and Blummel [11] found a significant positive correlation between haulm nitrogen content (by extension crude protein) and pod yield and between haulm nitrogen content and haulm yield. The same study also did not find any inverse association between either pod yield and haulm quality or haulm quality and haulm yield. These findings suggest that it is possible to develop groundnut genotypes that combine high pod yield and high haulm yield of good quality and nutritive value. Therefore, the objectives of this study were to

(i) identify groundnut genotypes with high pod and haulm yield for dual purpose utilization;

(ii) assess haulms of selected genotypes for nutritive quality traits.

\section{Materials and Methods}

2.1. Field Evaluation of Germplasm. The study was based on 30 groundnut genotypes (Table 1) which were obtained from different sources. They included 23 genotypes selected from a preliminary study involving 140 elite genotypes obtained from ICRISAT. The 23 genotypes were selected based on mean pod and haulm yield as well as days to physiological maturity. Reaction to leaf spot diseases was also considered for the selection. Five other genotypes introduced from other sources were also included. Genotypes NKATIESARI and CHINESE were included as local checks to aid comparison.
TABLE 1: List of genotypes evaluated on-station at Nyankpala in the 2015 cropping season.

\begin{tabular}{|c|c|c|}
\hline Number & Genotype & Source \\
\hline 1 & CHINESE & SARI, Ghana \\
\hline 2 & GAF 1665 & SARI, Ghana \\
\hline 3 & GAF 1723 & SARI, Ghana \\
\hline 4 & GK 7 & IER, Burkina Faso \\
\hline 5 & ICGV 91279 & ICRISAT, Mali \\
\hline 6 & ICGV 91315 & ICRISAT, Mali \\
\hline 7 & ICGV 00064 & ICRISAT, Mali \\
\hline 8 & ICGV-IS 08837 & ICRISAT, Mali \\
\hline 9 & ICGV-IS 13002 & ICRISAT, Mali \\
\hline 10 & ICGV-IS 13015 & ICRISAT, Mali \\
\hline 11 & ICGV-IS 13041 & ICRISAT, Mali \\
\hline 12 & ICGV-IS 13045 & ICRISAT, Mali \\
\hline 13 & ICGV-IS 13052 & ICRISAT, Mali \\
\hline 14 & ICGV-IS 13066 & ICRISAT, Mali \\
\hline 15 & ICGV-IS 13068 & ICRISAT, Mali \\
\hline 16 & ICGV-IS 13071 & ICRISAT, Mali \\
\hline 17 & ICGV-IS 13075 & ICRISAT, Mali \\
\hline 18 & ICGV-IS 13078 & ICRISAT, Mali \\
\hline 19 & ICGV-IS 13079 & ICRISAT, Mali \\
\hline 20 & ICGV-IS 13081 & ICRISAT, Mali \\
\hline 21 & ICGV-IS 13086 & ICRISAT, Mali \\
\hline 22 & ICGV-IS 13097 & ICRISAT, Mali \\
\hline 23 & ICGV-IS 13106 & ICRISAT, Mali \\
\hline 24 & ICGV-IS 13110 & ICRISAT, Mali \\
\hline 25 & ICGV-IS 13113 & ICRISAT, Mali \\
\hline 26 & ICGV-IS 13114 & ICRISAT, Mali \\
\hline 27 & ICGV-IS 13998 & ICRISAT, Mali \\
\hline 28 & NKATIESARI & SARI, Ghana \\
\hline 29 & SAMNUT 22 & Nigeria \\
\hline 30 & SAMNUT 23 & Nigeria \\
\hline
\end{tabular}

The field experiment was conducted at the research fields of Savanna Agricultural Research Institute in Nyankpala during the 2015 main cropping season. The location is on latitude $09^{\circ} 25^{\prime} 41^{\prime \prime} \mathrm{N}$ and longitude $000^{\circ} 58^{\prime} 42^{\prime \prime} \mathrm{W}$ at altitude $183 \mathrm{~m}$ above sea level. The annual mean rainfall of the area is between 900 and $1200 \mathrm{~mm}$. The soils of the experimental site are Ferric Luvisols of the Tingoli series with a brown colour, moderately drained, and free from concretions [27]. The experimental design used was a randomized complete block design with three replications. The genotypes were planted in 4 rows of $4 \mathrm{~m}$ length with spacing of $50 \mathrm{~cm} \times 15 \mathrm{~cm}$. Phosphorus was applied in the form of TSP at a rate of $60 \mathrm{~kg}$ $\mathrm{P}_{2} \mathrm{O}_{5}$ per ha at emergence. Plots were further supplemented with ground oyster shells (substitute for Gypsum to supply Ca) at a rate of $200 \mathrm{~kg} / \mathrm{ha}$. Data was collected on number of days to $50 \%$ flowering, haulm yield, pod yield, and yield components. 
The data was tested for normality after which it was analyzed following the ANOVA procedure in GenStat 12.1 [28]. Genotypic $\left(\sigma_{g}^{2}\right)$ and phenotypic $\left(\sigma_{p}^{2}\right)$ variances were computed using the expected mean squares from the analysis of variance table as described by [29]. Broad sense heritability $\left(H^{2}\right)$ was estimated according to the method described in [30] as follows:

$$
\begin{aligned}
& H^{2}=\frac{\sigma_{g}^{2}}{\sigma_{p}^{2}}, \\
& \sigma_{p}^{2}=\sigma_{g}^{2}+\left(\frac{\sigma_{e}^{2}}{R}\right),
\end{aligned}
$$

where $\sigma_{g}^{2}$ is genotypic variance, $\sigma_{p}^{2}$ is phenotypic variance, $\sigma_{e}^{2}$ is error variance, and $R$ is number of replications.

Phenotypic coefficient of variation (PCV) and genotypic coefficient of variation (GCV) estimates were obtained following the method described by [31].

$$
\begin{aligned}
& \operatorname{GCV}(\%)=\frac{\sqrt{ } \sigma_{g}^{2}}{\bar{x}} * 100, \\
& \operatorname{PCV}(\%)=\frac{\sqrt{ } \sigma_{p}^{2}}{\bar{x}} * 100,
\end{aligned}
$$

where $\bar{x}$ is grand mean of trait.

Expected genetic advance (GA) due to selection and genetic advance as a percentage of mean (GAM) was calculated as described by [30,32], assuming a selection intensity of $5 \%(2.06)$ as follows:

$$
\begin{aligned}
\mathrm{GA} & =i \sigma_{p} H^{2}, \\
\mathrm{GAM} & =\left(\frac{\mathrm{GA}}{\bar{x}}\right) * 100,
\end{aligned}
$$

where GA is genetic advance, $i$ is selection intensity, $\sigma_{p}$ is phenotypic standard deviation, $H^{2}$ is broad sense heritability, GAM is genetic advance as a percentage of mean, and $\bar{x}$ is grand mean.

2.2. Nutritive Quality Evaluation. Based on the results from the agronomic performance study with special emphasis on haulm and pod yield, six genotypes were selected for haulm nutritive quality evaluation. Three samples of each genotype were taken from 3 replicate plots after harvest. The samples were oven dried at $60^{\circ} \mathrm{C}$ for $48 \mathrm{~h}$ and milled to pass through $2 \mathrm{~mm}$ sieve. The samples were then analyzed at the nutrition laboratory of the University for Development Studies, in Nyankpala, Tamale.

2.2.1. Laboratory and Statistical Analysis. In vitro gas production (IVGP) was determined through fermentation. About $200 \mathrm{mg}$ triplicate samples of each of the haulms were placed in $100 \mathrm{ml}$ graduated glass syringe filled with $10 \mathrm{ml}$ of rumen fluid and $20 \mathrm{ml}$ of buffer. The rumen fluids were sampled from 2 slaughtered healthy rams in Tamale abattoir at $0700 \mathrm{~h}$ immediately after slaughter. The rumen fluid was squeezed through four layers of cheesecloth, mixed thoroughly, and kept at $39^{\circ} \mathrm{C}$ in a water bath under continuous flushing with $\mathrm{CO}_{2}$ before use. It was diluted with a cultured medium containing bicarbonate buffer, macro- and microminerals, and a reducing solution. The buffered rumen fluid $(30 \mathrm{ml})$ was pipetted into each syringe and syringes were immediately placed in a water bath at $39^{\circ} \mathrm{C}$ [33]. Gas production volumes were recorded at $0,6,12,24$, and $48 \mathrm{~h}$ of incubation and corrected for blank syringes incubated in each run.

Representative samples of each genotype were used for dry matter (DM), organic matter (OM), crude fibre (CF), and ash determination following the procedure of [34]. Nitrogen (N) content was measured by the Kjeldahl method [34]. Crude protein $(\mathrm{CP})$ was calculated as $\mathrm{N} \times 6.25$. Neutral detergent fibre (NDF) and acid detergent fibre (ADF) were determined according to [35]. Digestible organic matter (DOM) and metabolizable energy (ME) were calculated according to [33] with the the following equations.

$$
\begin{aligned}
& \text { DOM\% } \\
& \begin{aligned}
= & 5.38+(0.8453 \times 24 \text { h net gas } \mathrm{ml} / 200 \mathrm{ml} \mathrm{DM}) \\
& +(0.595 \times \mathrm{CP} \%)+(0.181 \times \mathrm{Ash} \%), \\
\mathrm{ME}(\mathrm{MJ} / \mathrm{Kg}) & \\
= & 2.2+(0.136 \times 24 \mathrm{~h} \text { net gas } \mathrm{ml} / 200 \mathrm{ml} \mathrm{DM}) \\
& +(0.0057 \times \mathrm{CP} / \mathrm{Kg} \mathrm{DM}),
\end{aligned}
\end{aligned}
$$

where DOM is digestible organic matter, ME is metabolizable energy, and $\mathrm{CP}$ is crude protein

The data on in vitro gas production and chemical composition of haulms were analyzed by ANOVA using GenStat Statistics ${ }^{\circledR}$ software [28]. Means were separated using LSD at 0.05 significance levels.

\section{Results and Discussion}

\subsection{Field Evaluation}

3.1.1. Summary Statistics and Analysis of Variance (ANOVA). The summary statistics on the agronomic performance of the genotypes used in this study are presented in Table 2. The analysis of variance revealed significant $(p<0.001)$ differences among the genotypes for the parameters measured. Number of days to $50 \%$ flowering ranged from 25 to 33 with a mean of 29 . Average number of pods per plant was 31 with some genotypes having as low as nine pods per plant and others as high as 72 pods per plant. The highest mean pod yield recorded was $6.2 \mathrm{tha}^{-1}$ with a mean of $2.76 \mathrm{tha}^{-1}$. Average haulm yield recorded was $7 \mathrm{tha}^{-1}$ with the highest being $14.4 \mathrm{tha}^{-1}$ and the lowest being $4.24 \mathrm{tha}^{-1}$. 100-seed weight ranged from $26.8 \mathrm{~g}$ to $48.5 \mathrm{~g}$. Shelling percentage and harvest index ranged from 54 to $73 \%$ and 20 to $62 \%$, respectively. 
TABLE 2: Summary statistics of 30 groundnut genotypes grown at Nyankpala in 2015.

\begin{tabular}{lccr}
\hline Trait & Mean & s.e.m. & Range \\
\hline Days to flowering & 29.0 & 0.21 & $25.0-33.0$ \\
Pod number $\left(\right.$ plant $\left.^{-1}\right)$ & 31.0 & 1.28 & $9.00-72.0$ \\
Pod yield $\left(\mathrm{t} \mathrm{ha}^{-1}\right.$ ) & 2.76 & 0.11 & $0.86-6.25$ \\
Shelling percentage (\%) & 63.2 & 0.40 & $54.0-73.0$ \\
100-seed weight $(\mathrm{g})$ & 35.7 & 0.55 & $26.8-48.5$ \\
Haulm yield $\left(\mathrm{t} \mathrm{ha}^{-1}\right)$ & 7.0 & 0.23 & $4.24-14.4$ \\
Harvest index $(\%)$ & 43.7 & 0.83 & $20.3-62.2$ \\
\hline
\end{tabular}

TABLE 3: Estimates of variance components, heritability, coefficient of variation, and genetic advance of 30 groundnut genotypes.

\begin{tabular}{|c|c|c|c|c|c|c|c|c|}
\hline Trait & $\sigma_{g}^{2}$ & $\sigma_{p}^{2}$ & $\sigma_{e}^{2}$ & $H^{2}$ & $\begin{array}{c}\text { GCV } \\
(\%)\end{array}$ & $\begin{array}{c}\text { PCV } \\
(\%)\end{array}$ & GA & $\begin{array}{c}\text { GAM } \\
(\%)\end{array}$ \\
\hline Days to flowering & 2.48 & 2.95 & 1.41 & 0.84 & 5.51 & 6.00 & 3.39 & 11.9 \\
\hline Pod number (plant ${ }^{-1}$ ) & 73.7 & 98.4 & 74.1 & 0.75 & 28.0 & 32.3 & 18.7 & 61.0 \\
\hline Pod yield $\left(\mathrm{t} \mathrm{ha}^{-1}\right)$ & 0.57 & 0.73 & 0.48 & 0.78 & 27.2 & 30.9 & 1.63 & 58.9 \\
\hline Shelling percentage (\%) & 6.28 & 9.13 & 8.55 & 0.68 & 3.96 & 4.78 & 5.34 & 8.44 \\
\hline 100-seed weight (g) & 7.27 & 12.7 & 16.3 & 0.57 & 7.55 & 9.98 & 6.11 & 17.1 \\
\hline Haulm yield $\left(\mathrm{t} \mathrm{ha}^{-1}\right)$ & 3.10 & 3.63 & 1.60 & 0.85 & 25.1 & 27.2 & 3.75 & 53.6 \\
\hline Harvest index (\%) & 18.5 & 32.6 & 42.4 & 0.57 & 9.85 & 13.1 & 9.19 & 21.0 \\
\hline
\end{tabular}

$\sigma_{g}^{2}$ : genotypic variance, $\sigma_{p}^{2}$ : phenotypic variance, $\sigma_{e}^{2}$ : error variance, $H^{2}$ : broad sense heritability, GCV: genotypic coefficient of variations, PCV: phenotypic coefficient of variation, GA: genetic advance, and GAM: genetic advance as a percentage of mean.

3.1.2. Variance Components, Heritability, and Coefficient of Variation. Estimates of variance components (genetic, phenotypic, and error), broad sense heritability, genotypic coefficient of variation, phenotypic coefficient of variation, genetic advance, and genetic advance as a percentage of the mean are presented in Table 3. Genetic variance was higher than error variance for number of days to $50 \%$ flowering, pod yield, and haulm yield. This is an indication that these traits were less influenced by the environment $[20,36]$. Consequently, broad sense heritability was high in these traits. On the other hand, genetic variance of number of pods per plant, 100 -seed weight, and harvest index were low compared to their error variances and therefore moderate broad sense heritability was recorded for these traits. The high broad sense heritability observed is an indication that direct selection for days to flowering, number of pods per plant, and pod yield can be done effectively [37]. The high broad sense heritability estimate is also an indication of the relatively uniform environment under which the trial was conducted [20].

Genotypic coefficient of variation (GCV) was highest for pod number per plant and pod yield and lowest in days to $50 \%$ flowering and 100 -seed weight. The same trend was observed for phenotypic coefficient of variation with pod number per plant and pod yield being the highest while shelling percentage and 100-seed weight showed the least GCV. Genetic advance was the highest in pod number per plant and the least in pod yield. However, it was haulm yield, number of pods per plant, and pod yield that recorded the highest genetic advance as a percentage of the mean. This is an indication that 61,59 , and $54 \%$ progress can be made in these three traits via selection among the genotypes evaluated.

\subsubsection{Mean Performance of Genotypes}

Number of Days to Flowering. There was a significant difference $(p<0.05)$ among the genotypes for days to $50 \%$ flowering. Flowering time in groundnut is indicative of the maturity period of genotype [38]. The late maturing groundnut genotypes generally took more days (>30 days after planting) to reach $50 \%$ flowering. On the other hand, early maturing genotypes such as ICGV-IS 13081, CHINESE, ICGV-IS 13078, ICGV-IS 91315, ICGV-IS 13075, and ICGV-IS 13041 reached 50\% flowering within 25-27 days after planting (see Table 4). This is consistent with previous reports which showed that early maturing genotypes flower earlier [39]. The genotypes combining early maturity and high pod yields will be important for the Guinea savanna agroecology of Ghana due to the increased shortening of the growing season. This is particularly important because of the observed end of year drought which is worsening as more erratic rainfall is being experienced currently [23]. They will also be important for high intensity multiple cropping system since they are suitable for double cropping either as intercrops or as sequence crops [38]. This provides opportunities for resource poor farmers to reduce risk associated with crop failure. The late maturing varieties like GAF 1665, GAF 1723, GK 7, SAMNUT 22, and ICGV-IS 13045 reached 50\% flowering after 30 days consistent with previous studies [39]. The medium maturing 
TABLE 4: Performance of 30 groundnut genotypes evaluated on-station at Nyankpala in 2015.

\begin{tabular}{|c|c|c|c|c|c|c|c|}
\hline Genotype & $\mathrm{DF}$ & $\begin{array}{l}\text { HYLD } \\
\left(\mathrm{tha}^{-1}\right)\end{array}$ & Pods per plant & $\begin{array}{c}\text { PYLD } \\
\left(\mathrm{tha}^{-1}\right)\end{array}$ & $\begin{array}{l}\mathrm{SH} \\
(\%)\end{array}$ & $\begin{array}{c}\text { 100-SW } \\
(\mathrm{g})\end{array}$ & $\begin{array}{l}\mathrm{HI} \\
(\%)\end{array}$ \\
\hline CHINESE & $25^{\mathrm{hj}}$ & $4.86^{j}$ & $21^{\mathrm{gh}}$ & $1.96^{\mathrm{gh}}$ & $68^{\mathrm{ac}}$ & $31.2^{\mathrm{eh}}$ & $43.9^{\text {be }}$ \\
\hline GAF 1665 & $30^{\mathrm{ac}}$ & $7.61^{\mathrm{bi}}$ & $34^{\mathrm{bg}}$ & $2.41^{\mathrm{dh}}$ & $67^{\mathrm{ad}}$ & $33.1^{\text {bh }}$ & $39.1^{\mathrm{cf}}$ \\
\hline GAF 1723 & $32^{\mathrm{a}}$ & $8.79^{\mathrm{bd}}$ & $46^{\text {ad }}$ & $3.71^{\text {be }}$ & $60^{\mathrm{fh}}$ & $40.9^{\mathrm{ab}}$ & $46.3^{\text {bd }}$ \\
\hline GK 7 & $31^{\mathrm{ab}}$ & $8.98^{b c}$ & $41^{\text {ae }}$ & $3.48^{\mathrm{bf}}$ & $65^{\mathrm{af}}$ & $38.1^{\text {af }}$ & $44.1^{\text {be }}$ \\
\hline ICGV 91279 & $28^{\mathrm{dh}}$ & $5.67^{\mathrm{fj}}$ & $28^{\mathrm{eh}}$ & $2.34^{\mathrm{eh}}$ & $62^{\mathrm{dh}}$ & $37.0^{\mathrm{ag}}$ & $44.9^{\text {be }}$ \\
\hline ICGV 91315 & $27^{\mathrm{ej}}$ & $5.55^{\mathrm{fj}}$ & $22^{\mathrm{gh}}$ & $1.96^{\mathrm{gh}}$ & $58^{\mathrm{h}}$ & $30.0^{\mathrm{fh}}$ & $39.6^{\mathrm{cf}}$ \\
\hline ICGV 00064 & $31^{\mathrm{ac}}$ & $5.82^{\mathrm{fj}}$ & $46^{\mathrm{ad}}$ & $3.29^{\mathrm{bg}}$ & $60^{\mathrm{fh}}$ & $40.4^{\mathrm{ac}}$ & $53.6^{\mathrm{ab}}$ \\
\hline ICGV-IS 08837 & $29^{\mathrm{cf}}$ & $7.82^{\mathrm{bg}}$ & $32^{\mathrm{cg}}$ & $3.31^{\mathrm{bg}}$ & $63^{\text {bh }}$ & $36.6^{\mathrm{ah}}$ & $45.8^{\mathrm{bd}}$ \\
\hline ICGV-IS 13002 & $28^{\mathrm{dg}}$ & $6.01^{\mathrm{ej}}$ & $29^{\mathrm{dh}}$ & $2.24^{\mathrm{fh}}$ & $65^{\text {bg }}$ & $42.1^{\mathrm{a}}$ & $42.2^{\mathrm{bf}}$ \\
\hline ICGV-IS 13015 & $31^{\mathrm{ac}}$ & $6.70^{\mathrm{cj}}$ & $24^{\mathrm{eh}}$ & $2.30^{\mathrm{fh}}$ & $61^{\mathrm{fh}}$ & $37.8^{\mathrm{af}}$ & $40.8^{\mathrm{bf}}$ \\
\hline ICGV-IS 13041 & $27^{\mathrm{ej}}$ & $5.34^{\mathrm{gj}}$ & $14^{\mathrm{h}}$ & $1.60^{\mathrm{h}}$ & $71^{\mathrm{a}}$ & $32.8^{\mathrm{ch}}$ & $37.0^{\mathrm{df}}$ \\
\hline ICGV-IS 13045 & $31^{\mathrm{ac}}$ & $9.36^{\mathrm{b}}$ & $29^{\mathrm{dh}}$ & $2.39^{\mathrm{dh}}$ & $62^{\mathrm{dh}}$ & $33.9^{\mathrm{bh}}$ & $32.5^{\mathrm{ef}}$ \\
\hline ICGV-IS 13052 & $28^{\mathrm{di}}$ & $6.35^{\mathrm{dj}}$ & $30^{\mathrm{dh}}$ & $2.73^{\mathrm{ch}}$ & $65^{\text {bg }}$ & $40.1^{\mathrm{ac}}$ & $46.2^{\text {bd }}$ \\
\hline ICGV-IS 13066 & $28^{\mathrm{di}}$ & $6.77^{\mathrm{cj}}$ & $21^{\mathrm{gh}}$ & $2.21^{\mathrm{fh}}$ & $61^{\mathrm{fh}}$ & $39.3^{\text {ae }}$ & $38.8^{\mathrm{cf}}$ \\
\hline ICGV-IS 13068 & $28^{\mathrm{di}}$ & $5.49^{\mathrm{fj}}$ & $27^{\mathrm{eh}}$ & $2.45^{\mathrm{dh}}$ & $64^{\mathrm{bg}}$ & $34.5^{\mathrm{ah}}$ & $44.9^{\text {be }}$ \\
\hline ICGV-IS 13071 & $28^{\mathrm{dg}}$ & $5.59^{\mathrm{fj}}$ & $29^{\mathrm{dh}}$ & $2.83^{\text {bh }}$ & $63^{\text {bh }}$ & $38.2^{\mathrm{ae}}$ & $50.3^{\mathrm{ac}}$ \\
\hline ICGV-IS 13075 & $27^{\mathrm{ej}}$ & $5.62^{f j}$ & $21^{\mathrm{gh}}$ & $2.03^{\mathrm{gh}}$ & $64^{\text {bh }}$ & $36.0^{\mathrm{ah}}$ & $40.7^{\mathrm{bf}}$ \\
\hline ICGV-IS 13078 & $26^{\mathrm{gj}}$ & $5.24^{\text {hj }}$ & $23^{\mathrm{fh}}$ & $2.48^{\mathrm{dh}}$ & $64^{\text {bg }}$ & $28.9^{\mathrm{h}}$ & $48.7^{\mathrm{ad}}$ \\
\hline ICGV-IS 13079 & $27^{\mathrm{dj}}$ & $6.17^{\mathrm{ej}}$ & $24^{\mathrm{eh}}$ & $2.28^{\mathrm{fh}}$ & $62^{\mathrm{dh}}$ & $36.9^{\mathrm{ag}}$ & $42.7^{\mathrm{bf}}$ \\
\hline ICGV-IS 13081 & $27^{\mathrm{fj}}$ & $8.46^{\text {be }}$ & $40^{\mathrm{af}}$ & $4.09^{\mathrm{b}}$ & $64^{\mathrm{bg}}$ & $37.5^{\mathrm{ag}}$ & $49.2^{\mathrm{ad}}$ \\
\hline ICGV-IS 13086 & $28^{\mathrm{di}}$ & $6.50^{\mathrm{dj}}$ & $30^{\mathrm{dh}}$ & $2.54^{\mathrm{ch}}$ & $62^{\mathrm{dh}}$ & $31.5^{\mathrm{dh}}$ & $44.1^{\text {be }}$ \\
\hline ICGV-IS 13097 & $28^{\mathrm{dg}}$ & $5.40^{\mathrm{fj}}$ & $21^{\mathrm{gh}}$ & $2.14^{\mathrm{fh}}$ & $63^{\text {bh }}$ & $37.7^{\mathrm{af}}$ & $43.8^{\text {be }}$ \\
\hline ICGV-IS 13106 & $27^{\mathrm{dj}}$ & $6.01^{\mathrm{ej}}$ & $23^{\mathrm{fh}}$ & $2.05^{\mathrm{gh}}$ & $60^{\mathrm{gh}}$ & $29.6^{\mathrm{gh}}$ & $40.6^{\mathrm{bf}}$ \\
\hline ICGV-IS 13110 & $28^{\mathrm{di}}$ & $5.49^{\mathrm{fj}}$ & $25^{\mathrm{eh}}$ & $2.42^{\mathrm{dh}}$ & $63^{\text {bh }}$ & $36.9^{\mathrm{ag}}$ & $46.8^{\mathrm{bd}}$ \\
\hline ICGV-IS 13113 & $27^{\mathrm{dj}}$ & $5.15^{\mathrm{ij}}$ & $22^{\mathrm{gh}}$ & $2.36^{\mathrm{eh}}$ & $63^{\mathrm{ch}}$ & $31.2^{\mathrm{eh}}$ & $47.8^{\mathrm{ad}}$ \\
\hline ICGV-IS 13114 & $31^{\mathrm{ac}}$ & $7.78^{\text {bh }}$ & $36^{\mathrm{bg}}$ & $3.35^{\mathrm{bg}}$ & $58^{\mathrm{h}}$ & $39.4^{\mathrm{ad}}$ & $45.1^{\text {be }}$ \\
\hline ICGV-IS 13998 & $31^{\mathrm{ac}}$ & $11.8^{\mathrm{a}}$ & $32^{\mathrm{cg}}$ & $2.58^{\mathrm{ch}}$ & $69^{\mathrm{ab}}$ & $35.2^{\text {ah }}$ & $30.1^{\mathrm{f}}$ \\
\hline NKATIESARI & $30^{\text {ad }}$ & $9.98^{\mathrm{ab}}$ & $47^{\mathrm{ac}}$ & $3.74^{\mathrm{bd}}$ & $67^{\mathrm{ae}}$ & $33.2^{\mathrm{bh}}$ & $43.2^{\text {be }}$ \\
\hline SAMNUT 22 & $30^{\mathrm{ac}}$ & $11.7^{\mathrm{a}}$ & $50^{\mathrm{ab}}$ & $3.84^{b c}$ & $63^{\text {bh }}$ & $36.2^{\mathrm{ah}}$ & $39.3^{\mathrm{cf}}$ \\
\hline SAMNUT 23 & $29^{\text {be }}$ & $7.93^{\mathrm{bf}}$ & $53^{\mathrm{a}}$ & $5.73^{\mathrm{a}}$ & $61^{\mathrm{eh}}$ & $34.6^{\mathrm{ah}}$ & $59.1^{\mathrm{a}}$ \\
\hline CV\% & 4.1 & 18.2 & 28.1 & 25.2 & 4.7 & 11.3 & 14.9 \\
\hline
\end{tabular}

DF: days to 50\% flowering, HYLD: dry haulm yield at harvest, PYLD: pod yield, SH: shelling percentage, 100-SW: weight of a 100 seeds, and HI: harvest index. Mean values followed by dissimilar letters in each column are significantly different $(p<0.05)$.

lines reached 50\% flowering between 27 and 30 days after sowing.

Haulm Yield. One major importance of groundnut in the Guinea savanna agroecology of Ghana is the use of the haulms for livestock feeding [4]. Groundnut haulms after harvest have a high economic value as they are sold to livestock farmers. The haulms also contain high amounts of nitrogen which has the potential to improve soil fertility when incorporated into the soil [22]. Therefore, groundnut varieties that combine high haulm yield with high pod yield are very desirable for farmers in the Guinea savanna agroecology of Ghana. Average haulm yield differed significantly $(p<0.05)$ among the genotypes and ranged from 4 to
$11.8 \mathrm{tha}^{-1}$ (see Table 4). Genotypes ICGV-IS 13998, SAMNUT 22, NKATIESARI, ICGV-IS 13081, ICGV-IS 13045, GAF 1723 , and GK 7 recorded haulm yield above $8 \mathrm{tha}^{-1}$. These genotypes exhibited higher tolerance to leaf spots infection (data not shown) and therefore maintained most of their foliage at the time of harvest. Contrary to this, CHINESE which is very susceptible to foliar diseases [40], shed most of its leaves by the time of harvest and therefore it is not surprising that it recorded the least haulm yield of $4 \mathrm{t} \mathrm{ha}^{-1}$ at the time of harvest (see Table 4).

Yield and Yield Components. Pod yield differed significantly $(p<0.05)$ among the genotypes evaluated in this trial (Table 4 ). Mean pod yield per genotype ranged from a low 
TABLE 5: In vitro gas production $(\mathrm{ml} / 200 \mathrm{mg} \mathrm{DM})$ of fermented groundnut haulm.

\begin{tabular}{lcccccccc}
\hline \multirow{2}{*}{ Hours of incubation } & \multicolumn{9}{c}{ Groundnut cultivars } \\
& NKATIESARI & GAF 1723 & ICGV-IS 13998 & ICGV 00064 & GAF 1665 & ICGV-IS 08837 & SED & $p$ value \\
\hline 6 & 3.85 & 4.30 & 4.50 & 4.84 & 4.98 & 5.05 & 0.79 & 0.64 \\
12 & 6.26 & 7.74 & 6.91 & 6.75 & 6.90 & 8.46 & 1.35 & 0.64 \\
24 & 9.20 & 10.9 & 10.1 & 9.18 & 9.41 & 11.3 & 1.70 & 0.71 \\
48 & 13.3 & 14.5 & 13.9 & 12.6 & 13.4 & 14.6 & 1.78 & 0.86 \\
\hline
\end{tabular}

SED $=$ standard errors of differences of means.

TABLE 6: Chemical composition of dual purpose cultivars of groundnut haulms.

\begin{tabular}{lcccccccc}
\hline \multirow{2}{*}{ Haulm chemical composition (\%) } & \multicolumn{4}{c}{ Groundnut cultivars } \\
& GAF 1665 & ICGV 00064 & NKATIESARI & GAF 1723 & ICGV-IS 08837 & ICGV-IS 13998 & SED & $p$ value \\
\hline Crude protein & $11.4^{\mathrm{b}}$ & $12.2^{\mathrm{b}}$ & $12.0^{\mathrm{b}}$ & $12.5^{\mathrm{b}}$ & $8.50^{\mathrm{a}}$ & $11.3^{\mathrm{b}}$ & 11.3 & 0.034 \\
Ash & 7.37 & 6.90 & 6.18 & 6.55 & 5.96 & 8.00 & 1.01 & 0.389 \\
Crude fibre & $24.8^{\mathrm{a}}$ & $23.7^{\mathrm{a}}$ & $23.6^{\mathrm{a}}$ & $23.2^{\mathrm{a}}$ & $35.5^{\mathrm{b}}$ & $22.6^{\mathrm{a}}$ & 2.14 & 0.001 \\
NDF & 58.2 & 53.1 & 54.9 & 55.1 & 60.7 & 54.7 & 2.89 & 0.179 \\
ADF & $50.7^{\mathrm{b}}$ & $48.1^{\mathrm{ab}}$ & $50.1^{\mathrm{ab}}$ & $43.8^{\mathrm{a}}$ & $59.4^{\mathrm{c}}$ & $47.6^{\mathrm{ab}}$ & 2.91 & 0.004 \\
DOM & 54.5 & 54.5 & 52.6 & 60.2 & 62.0 & 57.5 & 6.88 & 0.722 \\
ME (MJ/kg DM) & 12.7 & 14.3 & 14.7 & 15.7 & 15.4 & 15.2 & 1.03 & 0.077 \\
\hline
\end{tabular}

Means with different superscript along the rows are significant at $p<0.05 . \mathrm{NDF}=$ neutral detergent fibre, ADF $=$ acid detergent fibre, DOM $=$ digestible organic matter, and $\mathrm{ME}=$ metabolizable energy.

of $1.6 \mathrm{tha}^{-1}$ to a high of $5.7 \mathrm{tha}^{-1}$. Outstanding genotypes were SAMNUT 23 and ICGV-IS 13081 with pod yield above $4 \mathrm{tha}^{-1}$. Other high performing genotypes included NKATIESARI $\left(3.74 \mathrm{tha}^{-1}\right)$, SAMNUT $22\left(3.84 \mathrm{tha}^{-1}\right)$, ICGV-IS $08837\left(3.31 \mathrm{tha}^{-1}\right)$, IGCV-IS $13114\left(3.35 \mathrm{tha}^{-1}\right)$, ICGV $00064\left(3.29 \mathrm{tha}^{-1}\right)$, GAF $1723\left(3.71 \mathrm{tha}^{-1}\right)$, and GK $7\left(3.48 \mathrm{tha}^{-1}\right)$. Among the genotypes introduced from ICRISAT Mali, ICGV-IS 13081 was very outstanding as it produced better pod yield than the check varieties NKATIESARI and SAMNUT 22, which are medium to late maturing. This observation was contrary to earlier reports that associated generally poor yields with early maturing genotypes compared to late maturing genotypes [39-42].

Yield components including shelling percentage, 100seed weight, and harvest index all differed significantly $(p<$ $0.05)$ among the genotypes. Shelling percentage ranged from 58\% in ICGV 91315 to $71 \%$ in ICGV-IS 13041. This result is consistent with previous reports [38]. On the other hand, 100 -seed weight which is an indication of seed size showed that genotypes GAF 1723, ICGV 00064, IGCV-IS 13002, and ICGV-IS 13052 had a relatively larger seed size (>40 g). On the other hand, genotypes ICGV-IS 13106 and ICGV-IS 13078 had smaller seed size and recorded 100 -seed weight of $28.9 \mathrm{~g}$ and $29.6 \mathrm{~g}$, respectively. Harvest index (HI), representing the proportion of the total crop biomass that has economic importance was the highest in genotypes SAMNUT 22 (59\%), ICGV 00064 (54\%), and ICGV-IS 13071. ICGV-IS 13998 displayed the least harvest index of $30.1 \%$ (see Table 4).

3.2. Nutritive Quality Evaluation. Six genotypes were selected and evaluated for nutritive quality of their haulms. The selection was based on the haulm and/or pod yield and genotypes that recorded high values for these traits were selected. The in vitro gas production rate of the haulms of the six selected groundnut genotypes evaluated were similar from $6 \mathrm{~h}(p=0.635)$ up to 48 ( $p=0.865)$ (Table 5). The volume of rumen gas produced ranged from 3.85 to $5.05 \mathrm{ml} / 200 \mathrm{mg}$ $\mathrm{DM}$ and 12.65 to $14.66 \mathrm{ml} / 200 \mathrm{mg} \mathrm{DM}$ at $6 \mathrm{~h}$ and $48 \mathrm{~h}$, respectively. ICGV-IS 08837 produced the highest volume of gas while ICGV 00064 recorded the lowest gas production rate at $6 \mathrm{~h}$. At $48 \mathrm{~h}$ of fermentation, the highest volume of gas was 14.66 and $14.52 \mathrm{ml} / 200 \mathrm{mg} \mathrm{DM}$, respectively, observed in ICGV-IS 08837 and GAF 1723. The lowest gas produced $(12.65 \mathrm{ml} / 200 \mathrm{mg} \mathrm{DM})$ was observed in ICGV 00064. Figure 1 presents the pictorial view of gas production. In vitro gas production levels were used to estimate digestible organic matter and metabolizable energy content of the haulms. In vitro gas production technique is used extensively to estimate rumen degradation of feedstuffs and prediction of feed nutritive quality [33].

Genotypic differences affected $(p=0.034)$ crude protein content of the haulms (see Table 6). The highest value (12.53\%) was obtained in GAF 1723 and the lowest (8.00\%) in ICGV-IS 08837. The paper [11] also reported large genotypic variation in $\mathrm{CP}$ of groundnut haulms when they evaluated 860 groundnut cultivars in different replicated trials. The list of the cultivars in an increasing order of $\mathrm{CP}$ content were ICGV-IS 08837, ICGV-IS 1399, GAF 1665, NKATIESARI, ICV-IS 00064, and GAF 1723 (Table 6). The CP content of all the cultivars fell within the reported range of 8 to $15 \%[11,12]$. There is still an opportunity for improving the groundnut haulm CP content since none of the genotypes' $\mathrm{CP}$ level got to the upper limit of $15 \%$ reported in literature. 


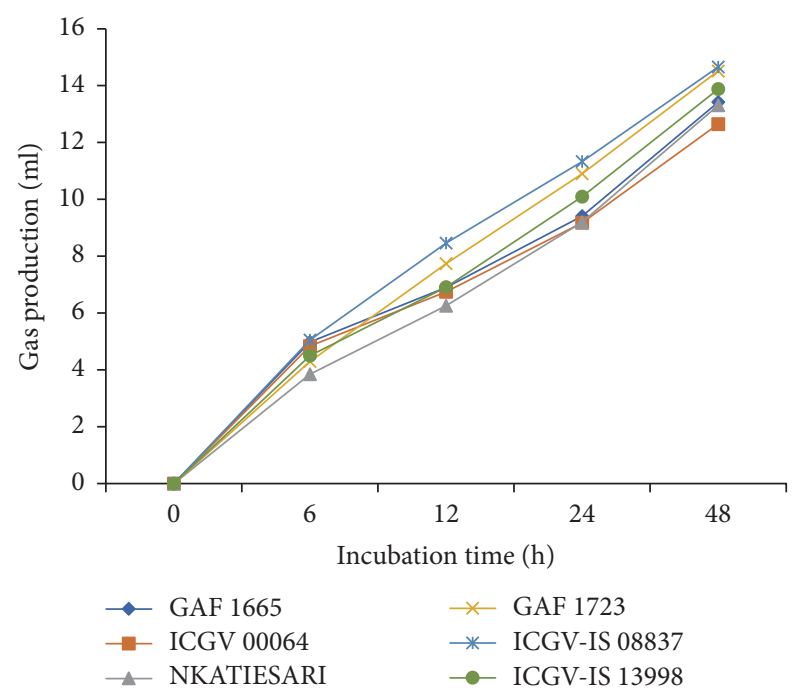

FIGURE 1: In vitro gas production rate of dual purpose groundnut haulms fermented with rumen fluid at different time periods.

Since there is no inverse relationship between the CP of groundnut haulms and haulm yield [11], the two traits could be improved concurrently. The CP content is an important indication of nutritional quality since the cultivars are often used as supplements for poor quality natural pasture and crop residues [43]. The differences in CP content among the cultivars evaluated and in reported literature may be due to genetic improvement of the cultivars and/or inherent genetic characteristics [44, 45]. Antwi et al. [43] observed similar genetic variability in evaluating the haulm quality of cowpea cultivars. Acid detergent fibre content was also significantly different $(p=0.004)$ among the six cultivars evaluated (Table 6). The genotype ICGV-IS 08837 had the highest ADF content (59\%) with GAF 1723 having the lowest $(43.80 \%)$ in a reverse form of the CP content. Crude fibre level of the haulms was also significantly higher $(p=0.001)$ in ICGV-IS 08837 whereas the other 5 cultivars' haulm CF were similar (see Table 6). Generally, forage with high ADF suggests that it is inferior in quality, has poor digestibility, and decreases animal growth when fed for a long period without other feed [46]. Ash, neutral detergent fibre, digestibility of organic matter, and metabolizable energy content of haulms of all cultivars evaluated were similar (Table 6) and fairly comparable to good forage values as feed for ruminants [11, 12].

In conclusion, the nutritive values of the 6 cultivars were all averagely good and can support the productive performance of ruminants when offered in appropriate quantities. Comparatively, GAF 1723 had the highest nutritive value due to its high CP concentration and low ADF content and ICGV-IS 08837 had the lowest attribute of nutritive quality because of low CP and high ADF concentration. GAF 1723 cultivar therefore has the superior groundnut haulm as a feed for ruminants. Again, the high yielding potential of the early maturing (90-95 days after planting) genotype ICGVIS 08837 makes it a suitable candidate for the Guinea savanna ecology of Ghana in the face of erratic rainfall distribution and shortening of the cropping cycle.

\section{Conflicts of Interest}

The authors declare there are no conflicts of interest regarding the publication of this article.

\section{Acknowledgments}

The authors wish to express their profound gratitude to CSIRSARI and ICRISAT for technical support and the Tropical Legumes III project and WAAPP 2A for the financial support. The gratitude is also extended to all colleagues who read the manuscript and made meaningful suggestions to complete it.

\section{References}

[1] MoFA-SRID., "Agriculture in Ghana: facts and figures, Minist," in Ministry Of Food and Agriculture / Statistics Research Information Directoriate, pp. 1-53, 2014.

[2] F. K. Tsigbey, R. L. Brandenburg, and V. A. Clottey, "Peanut production methods in northern Ghana and some disease perspectives," European Journal of Agronomy, vol. 34, pp. 36-47, 2003.

[3] J. Y. Asibuo, R. Akromah, O. Safo-Kantanka, H. K. Adu-Dapaah, S. Ohemeng-Dapaah, and A. Agyeman, "Chemical composition of groundnut, Arachis hypogaea (L) landrace," African Journal of Biotechnology, vol. 7, pp. 2203-2208, 2008.

[4] E. Martey, A. N. Wiredu, and R. Oteng-Frimpong, Baseline Study of Groundnut in Northern Ghana, LAP Lambert academic publishing, 2015.

[5] F. D. Dakora, R. A. Aboyinga, Y. Mahama, and J. Apaseku, "Assessment of N2 fixation in groundnut (Arachis hypogaea L.) and cowpea (Vigna unguiculata L. Walp) and their relative $\mathrm{N}$ contribution to a succeeding maize crop in Northern Ghana," Mircen Journal of Applied Microbiology and Biotechnology, vol. 3, no. 4, pp. 389-399, 1987.

[6] S. N. Mokgehle, F. D. Dakora, and C. Mathews, "Variation in N2 fixation and $\mathrm{N}$ contribution by 25 groundnut (Arachis hypogaea L.) varieties grown in different agro-ecologies, measured using $15 \mathrm{~N}$ natural abundance," Agriculture, Ecosystems and Environment, vol. 195, pp. 161-172, 2014.

[7] B. B. Singh, A. Musa, H. A. Ajeigbe, and S. A. Tarawali, "Effect of feeding crop residues of different cereals and legumes on weight gain of Yankassa rams," International Journal of Livestock Production, vol. 2, pp. 17-23, 2011.

[8] K. V. S. V Prasad, A. A. Khan, S. Vellaikumar et al., "Observations on livestock productivity in sheep fed exclusively on haulms from ten different genotypes of groundnut," Animal Nutrition and Feed Technology, vol. 10s, pp. 121-126, 2010.

[9] J. M. Forbes, The Voluntary Food Intake of Farm Animals, Butterworth \& Co. Ltd, London, UK, 1986.

[10] N. K. Ribadiya, H. H. Savsani, S. S. Patil et al., "Effect of feeding varying levels of groundnut haulms on feed intake and growth performance in broiler chickens," Veterinary World, vol. 8, no. 2, pp. 139-142, 2015.

[11] S. N. Nigam and M. Blummel, "Cultivar-dependent variation in food-feed-traits in groundnut (Arachis hypogaea L.)," Animal Feed Science and Technology, vol. 10s, pp. 39-48, 2010. 
[12] Y. Ozyigit and M. Bilgen, "Forage potential of some groundnut (Arachis hypogaea L.) cultivars," Romanian Agricultural Research, pp. 57-63, 2013.

[13] A. A. Ayantunde, S. Fernandez-rivera, and A. Dan-Gomma, "Sheep fattening with groundnut haulms and millet bran in the West African Sahel," Revue D'élevage Et De Médecine Vétérinaire Des Pays Tropicaux, vol. 61, pp. 215-220, 2008.

[14] N. Karbo, W. S. Alhassan, S. A. Adongo, and J. Bruce, "Small holder lamb fattening based on crop residues and agro-industrial by-products in northern Ghana," Ghana Journal of Agricultural Science, vol. 30, pp. 31-38, 1997.

[15] FAO, FAOSTAT, 2014, http://faostat.fao.org/site/339/default .aspx.

[16] S. K. Nutsugah, M. Abudulai, C. Oti-Boateng, R. L. Brandenburg, and D. L. Jordan, "Management of leaf spot diseases of peanut with fungicides and local detergents in Ghana," Plant Pathology Journal, vol. 6, no. 3, pp. 248-253, 2007.

[17] J. B. Naab, S. S. Seini, K. O. Gyasi et al., "Groundnut yield response and economic benefits of fungicide and phosphorus application in farmer-managed trials in Northern Ghana," Experimental Agriculture, vol. 45, no. 4, pp. 385-399, 2009.

[18] A. Arunyanark, S. Jogloy, S. Wongkaew et al., "Association between aflatoxin contamination and drought tolerance traits in peanut," Field Crops Research, vol. 114, no. 1, pp. 14-22, 2009.

[19] F. Hamidou, A. Rathore, F. Waliyar, and V. Vadez, "Although drought intensity increases aflatoxin contamination, drought tolerance does not lead to less aflatoxin contamination," Field Crops Research, vol. 156, pp. 10-110, 2014.

[20] F. Hamidou, P. Ratnakumar, O. Halilou et al., "Selection of intermittent drought tolerant lines across years and locations in the reference collection of groundnut (Arachis hypogaea L.)," Field Crops Research, vol. 126, pp. 189-199, 2012.

[21] V. Vadez, J. D. Berger, T. Warkentin et al., "Adaptation of grain legumes to climate change: A review," Agronomy for Sustainable Development, vol. 32, no. 1, pp. 31-44, 2012.

[22] B. D. K. Ahiabor, M. Fosu, E. Atsu, I. Tibo, and I. Sumaila, "Integrated soil fertility management for increased maize production in the degraded farmlands of the guinea savanna zone of ghana using devil-bean (crotalaria retusa) and fertilizer nitrogen," in Innovations as Key to the Green Revolution in Africa, A. Bationo, B. Waswa, J. M. Okeyo, F. Maina, and J. M. Kihara, Eds., pp. 183189, Springer, Dordrecht, Netherlands, 2011.

[23] C. Rademacher-Schulz, B. Schraven, and E. S. Mahama, "Time matters: Shifting seasonal migration in Northern Ghana in response to rainfall variability and food insecurity," Climate and Development, vol. 6, no. 1, pp. 46-52, 2014.

[24] S. P. Konlan, P. K. Karikari, and T. Ansah, "Productive and blood indices of dwarf rams fed a mixture of rice straw and groundnut haulms alone or supplemented with concentrates containing different levels of shea nut cake," Pakistan Journal of Nutrition, vol. 11, no. 6, pp. 566-571, 2012.

[25] K. Oppong-Apane, Cassava as Animal Feed in Ghana: Past, Present and Future, Food and Agriculture Organisation of the United Nations, Accra, Ghana, 2013.

[26] S. P. Konlan, A. A. Ayantunde, H. K. Dei, and F. K. Avornyo, Evaluation of Existing And Potential Feed Resources for Ruminant Production in Northern Ghana, International Livestock Research Institute, 2014.

[27] W. K. Atakora and P. K. Kwakye, "Measurement and modeling nitrous oxide emissions from ferric luvisols in the guinea savanna agro-ecological zone of Ghana," International Journal of Plant \& Soil Science, vol. 10, no. 3, pp. 1-8, 2016.
[28] R. W. Payne, D. A. Murray, S. A. Harding, D. B. Baird, and D. M. Soutar, Genstat for Windows, Edition Introduction, VSN International, Hemel Hempstead, 12th edition, 2009.

[29] P. Ntawuruhunga and A. G. O. Dixon, "Quantitative variation and interrelationship between factors influencing cassava yield," Journal of Applied Biosciences, vol. 26, pp. 1594-1602, 2010.

[30] G. Acquaah, "Principles of Plant Genetics and Breeding: Second Edition," Principles of Plant Genetics and Breeding: Second Edition, 2012.

[31] K. Singh and B. Chaudhary, Biometrical Methods in Quantitative Genetics Analysis, Kalyani Publishers, 1979.

[32] J. Adjebeng-Danquah, V. E. Gracen, S. K. Offei, I. K. Asante, and J. Manu-Aduening, "Agronomic performance and genotypic diversity for morphological traits among cassava genotypes in the Guinea Savannah Ecology of Ghana," Journal of Crop Science and Biotechnology, vol. 19, no. 1, pp. 99-108, 2016.

[33] K. H. Menke and H. Steingass, "Estimation of the energetic feed value obtained from chemical analysis and gas production using rumen fluid," Animal Research and Development, vol. 28, pp. 7$55,1988$.

[34] AOAC, AOAC Official Methods of Analysis, Journal of the Association of Official Agricultural Chemists, Virginia, VA, USA, 1992.

[35] P. J. van Soest, Nutritional Ecology of the Ruminant, Comstock Publisher, 1994.

[36] J. Adjebeng-Danquah, Genetic Studies of Physiological And Morphological Traits Associated with Drought Tolerance in Cassava Genotypes, University of Ghana, 2014.

[37] B. R. Ntare and J. H. Williams, "Heritability and genotype $\times$ environment interaction for yield and components of yield model in segregating populations of groundnut under semiarid conditions," African Crop Science Journal, vol. 6, pp. 119-127, 1998.

[38] H. D. Upadhyaya, L. J. Reddy, C. L. L. Gowda, and S. Singh, "Identification of diverse groundnut germplasm: Sources of early maturity in a core collection," Field Crops Research, vol. 97, no. 2-3, pp. 261-271, 2006.

[39] M. A. Coulibaly, B. R. Ntare, V. E. Gracen, E. Y. Danquah, K. Ofori, and A. S. Mahamane, "Phenotyping groundnut genotypes to identify sources of earliness in niger," International Journal of Innovations in Engineering Research and Technology (IJIERT), vol. 4, 238, p. 242, 2017.

[40] F. K. Padi, "Genotype x environment interaction for yield and reaction to leaf spot infections in groundnut in semiarid West Africa: Genotype x environment interaction and leaf spot resistance in groundnut," Euphytica, vol. 164, no. 1, pp. 143-161, 2008.

[41] A. K. Culbreath, J. W. Todd, D. W. Gorbet et al., "Response of early, medium, and late maturing peanut breeding lines to field epidemics of tomato spotted wilt," Peanut Science, vol. 26, no. 2, pp. 100-106, 1999.

[42] K. O. Marfo and F. K. Padi, "Yield stability of some groundnut accessions in northern Ghana," Ghana Journal of Agricultural Science, vol. 32, no. 2, pp. 137-144, 1999.

[43] C. Antwi, E. L. K. Osafo, A. Donkoh, and H. K. Adu-Dapaah, "Chemical composition, gas production and degradation characteristics of haulms of improved dual purpose Cowpea (Vigna unguiculata 1. walp) cultivars Livestock Research for Rural Development," Livestock Research for Rural Development, vol. 26, no. 11, pp. 1-9, 2014. 
[44] V. C. Badve, P. R. Nisal, A. L. Joshi, and D. V. Rangnekar, "Genotype and environment effects on sorghum stover production and quality," in Fibrous Crop Residues, L. Joshi, P. T. Doyle, S. J. Oosting, and V. Quant Qual, Eds., p. 9, Baif Development Research Foundation, Pune, India, 1994.

[45] S. Kiran and J. B. Schiere, Indo-Dutch Project on Bioconversion of Crop Residues, Indo-Dutch Project on Bioconversion of Crop Residues, New Delhi, India, 1995.

[46] E. Owen, "Cereal crop residues as feed for goats and sheep," Livestock Research for Rural Development, vol. 6, pp. 1-15, 1994. 


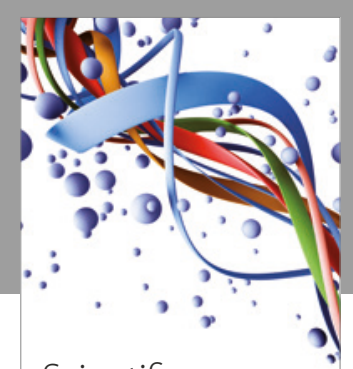

Scientifica
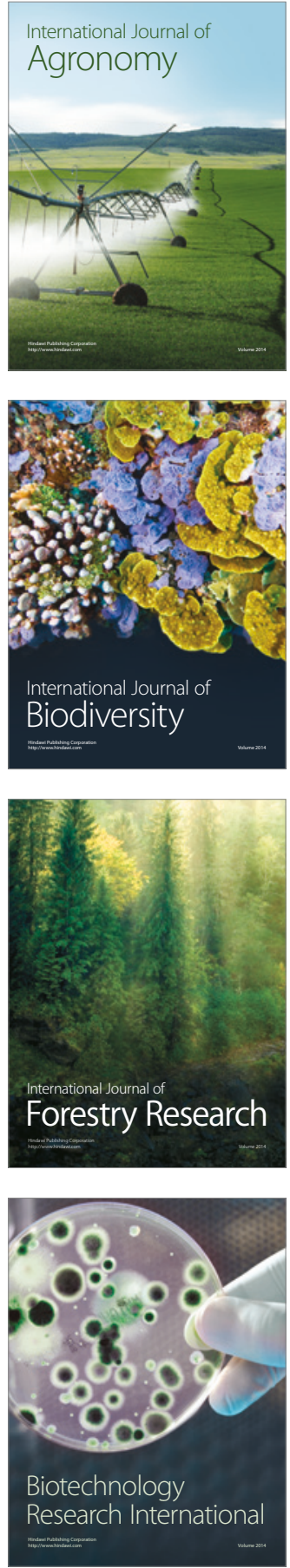
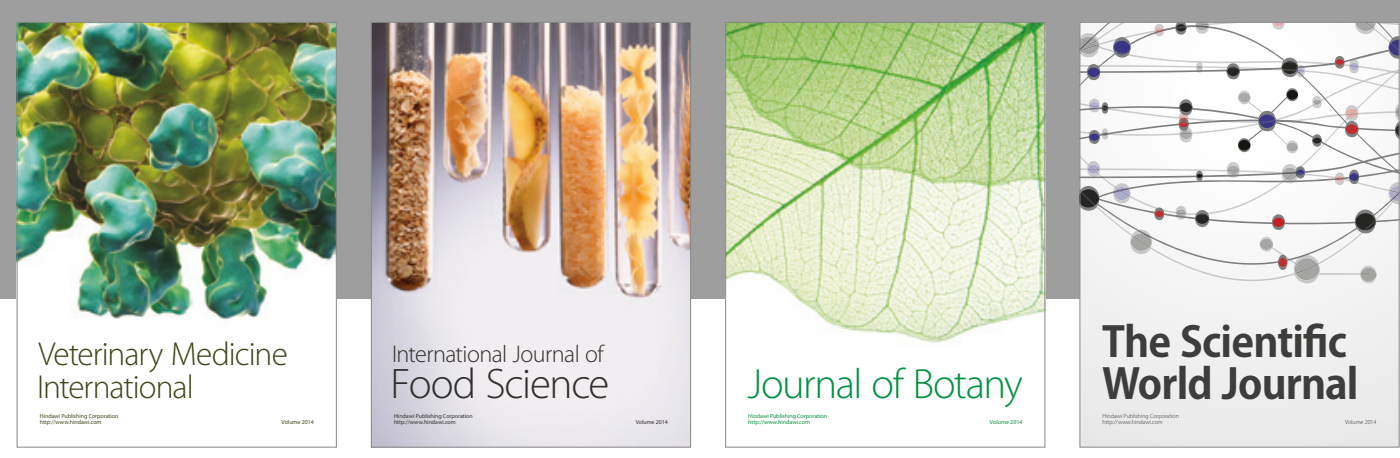

The Scientific

\section{World Journal}

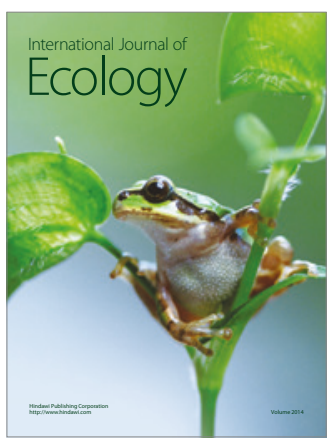

\section{Hindawi}

Submit your manuscripts at

https://www.hindawi.com
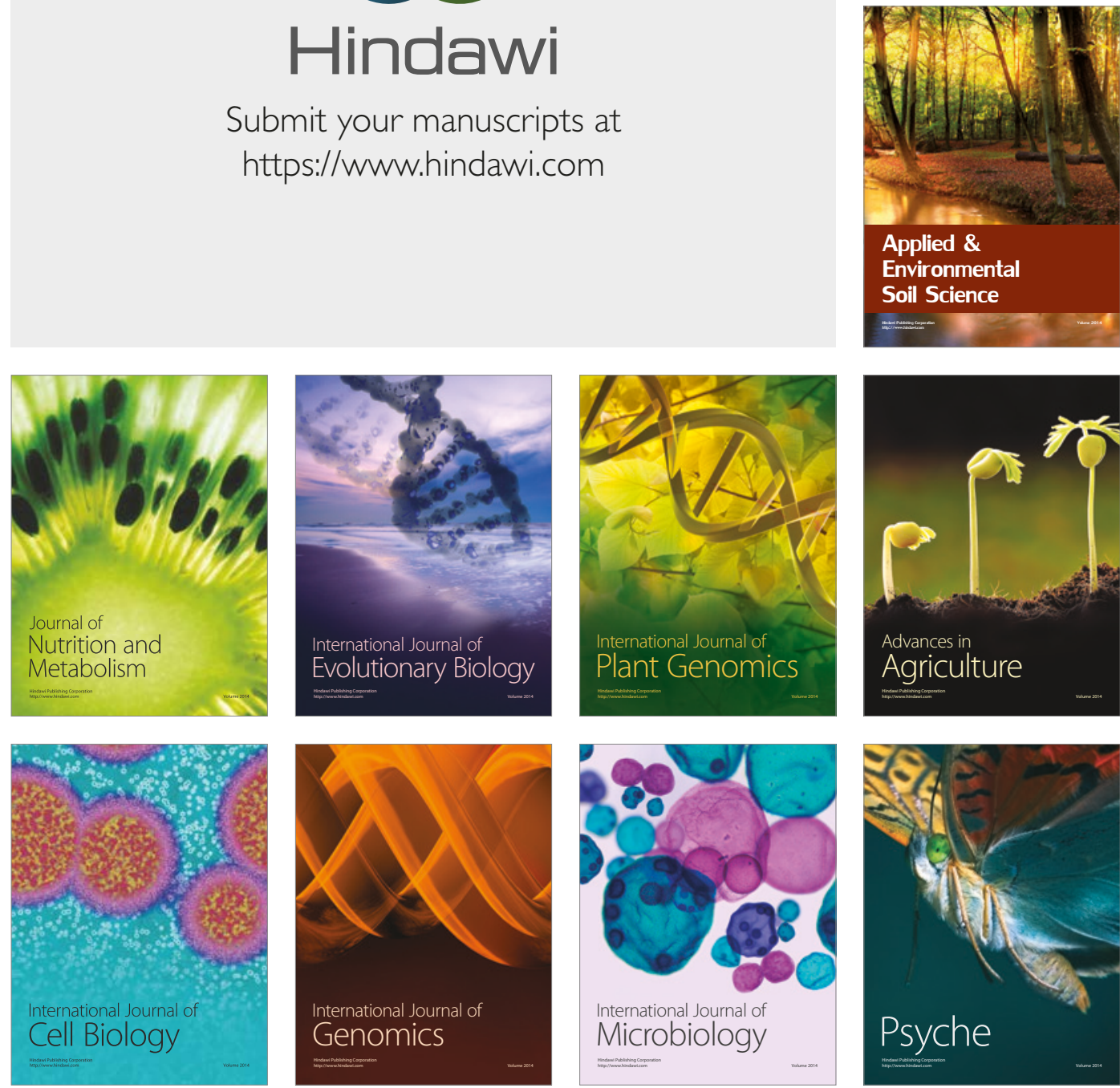

hternational Journal of Microbiology
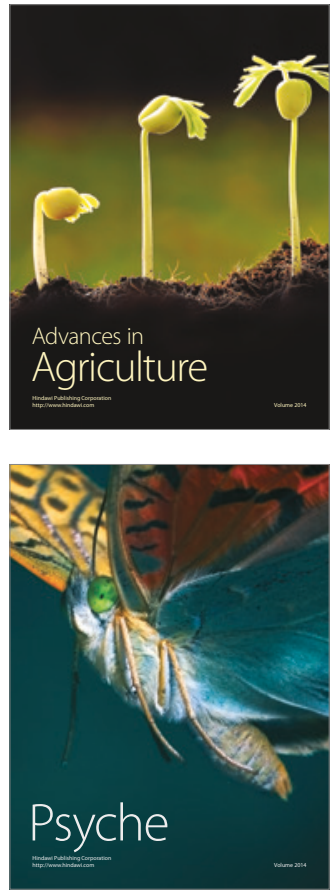